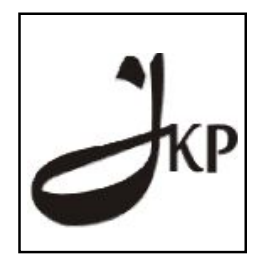

Info Artikel:

Diterima 06/06//2015

Direvisi 12/06/2015

Dipublikasikan 30/06/2015

\section{Jurnal Konseling dan Pendidikan}

ISSN Cetak: 2337-6740 - ISSN Online: 2337-6880

http://jurnal.konselingindonesia.com

Volume 3 Nomor 2, juni 2015, HIm 15-21

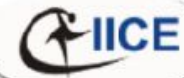

MULTIKARYA KONS

\title{
Token Economy (Hadiah) untuk Penyelesaian Tugas dalam Layanan Penguasaan Konten
}

Yeni Satroma Dewi, Herman Nirwana, \& Neviyarni S

Universitas Negeri Padang

\begin{abstract}
To learn so far a bout token economy in the completion students task at V grade in SD N 16 Sungayang. This research includes qualitative research with this type of case studies. The invent of this research show that applying token economy has a great influence to ward students behave in the completion mathematic task in the class. The implication application of token economy can support the implementation of service delivery mastery of content in completing learning tasks and giving other Guidance. A counselor can collaborate with some of the teachers to improve students behavior and students quality. It is hoped to the next beseecher to apply token economy in the different field to get more view.
\end{abstract}

Keyword: Token Economy (Gift), Completion of Task

Copyright ( 2015 IICE - Multikarya Kons (Padang - Indonesia) dan IKI - Ikatan Konselor Indonesia - All Rights Reserved

Indonesian Institute for Counseling and Education (IICE) Multikarya Kons

\section{PENDAHULUAN}

Guru menginginkan setiap peserta didiknya menciptakan kondisi belajar yang optimal, yaitu bertingkahlaku sesuai dengan aktivitas kelas agar mereka berhasil belajar. Namun yang terjadi di sekolah peserta didik bertingkahlaku bermasalah dalam belajar. Misalnya melanggar disiplin belajar, menyontek, tidak mengerjakan tugas, suka berjalan dan berpindah-pindah tempat duduk, keluar tanpa permisi ketika jam pelajaran berlangsung, bolos dan sering absen.

Berdasarkan hasil wawancara peneliti dengan guru kelas V SD Negeri 16 kecamatan Sungayang pada hari Selasa 10 Januari 2012 dan Kamis 24 Mei 2012 terungkap bahwa mereka merasa kewalahan dan bosan menghadapi perilaku anak yang bermasalah. Mereka justru berharap peserta didik yang bermasalah tersebut menjadi jera karena selalu tinggal kelas lalu berhenti dengan sendirinya.

Berbagai usaha telah dilakukan guru untuk menyelesaikan masalah belajar. Menentukan pendekatan pengajaran yang tepat dalam belajar adalah untuk menarik perhatian peserta didik dan menjadikan mereka senang belajar. Memberi petunjuk, menasehati, merubah strategi mengajar dan belajar yang konkrit merupakan pendekatan yang sering dilakukan guru untuk mencapai tujuan proses belajar mengajar dengan baik.

Kenyataannya, berdasarkan hasil wawancara pada hari Kamis 24 Mei 2012 tentang penyelesaian tugas-tugas belajar dengan guru kelas V SD Negeri 16 kecamatan Sungayang terungkap bahwa, dari sekian banyak mata pelajaran dan tugas yang harus dikerjakan, peserta didik kesulitan dalam menyelesaikan tugas pada mata pelajaran matematika. Ketika guru memberikan tugas, peserta didik tidak memanfaatkan waktu yang disediakan dengan sebaik-baiknya. Padahal setelah guru menjelaskan, guru mengevaluasi; peserta didik menunjukkan bahwa mereka sudah mengerti dan paham. Sehingga sering tugas yang semestinya dikerjakan di kelas, akhirnya menjadi Pekerjaan Rumah (PR).

Dalam matematika ada masalah yang tidak rutin (non-rutine problem). Masalah seperti ini dirancang atau dibuat agar peserta didik tertantang untuk menyelesaikan. Meskipun peserta didik awalnya mengalami kesulitan mengerjakannya, mereka menjadi terbiasa dan cerdas memecahkan masalah setelah mereka memperoleh banyak tugas. Prayitno (2012: 89) mengemukakan bahwa, "untuk menguasai kemampuan atau kompetensi tertentu 
melalui kegiatan belajar, peserta didik diberikan 'Layanan Penguasaan Konten (PKO)'”. Untuk mengetahui penguasaan peserta didik dalam proses belajar, mereka diberikan tugas. Hergenhahn \& Olson (2008) mengemukakan bahwa tugas itu penting; tugas memberi umpan balik (feedback) bagi pembelajaran dan guru mengenai proses belajar. Jika peserta didik menguasai pelajaran dengan baik, mereka akan dengan cepat diperkuat. Jika peserta didik mempelajari sesuatu secara salah, kesalahan itu harus dikoreksi secepatnya.

Namun, seperti apa yang dikemukakan Prayitno (2009) bahwa dalam praktik pendidikan sehari-hari banyak sekali kesalahan peserta didik yang menjadi perhatian guru dari pada kebaikan peserta didik. Agar peserta didik benar-benar belajar, sekolah menerapkan sistem poin untuk menghitung tingkahlaku peserta didik yang bermasalah. Misalnya, banyak guru-guru peserta diklat sertifikasi guru profesional pada tahun 2010-2011 pada berbagai kuota yang mengakui bahwa di sekolah mereka menerapkan sistem pemberian poin terhadap tingkahlaku peserta didik yang bermasalah. Namun tetap saja tingkahlaku peserta didik yang bermasalah tidak berubah, bahkan peserta didik yang mendapatkan poin tersebut memunculkan tingkahlaku bermasalah yang baru.

Thornburg (1984: 425) mengemukakan bahwa "the researchers found students disliked teachers who publicly criticized and privately praised them". Maksudnya adalah para peneliti menemukan peserta didik tidak menyukai guru yang terang-terangan mengkritik dan memuji pribadi mereka. Hal tersebut terbukti juga dengan pengakuan peserta didik yang pernah mendapatkan poin atas tingkahlaku buruknya yang pernah peneliti wawancarai pada bulan Mei 2012, bahwa mereka merasa kecewa, malu, mendongkol dan sangat tidak menyukai tingkahlaku buruknya menjadi perhatian guru piket, bahkan menganggap guru yang memberi poin berlebihan terhadap kesalahan mereka, meskipun itu tidak disengaja. Begitu juga pengakuan alumni, meskipun mereka sudah 2 (dua) tahun tamat, hal yang paling tidak disenangi masih teringat oleh dia ketika di sekolah lamanya adalah memperoleh poin atas kesalahan yang ia lakukan meskipun itu tidak disengaja.

Peristiwa di atas jelas menggambarkan bahwa sesungguhnya penguatanlah yang dibutuhkan oleh peserta didik dalam belajar. Pemberian penguatan dapat mendorong peserta didik belajar bertingkahlaku lebih baik lagi atau setidaknya mempertahankan tingkahlaku yang sudah baik. Kalau sering diberi penguatan terhadap apa yang dilakukan maka akan menjadi kebiasaan bagi dia. Walaupun untuk pertama kali kita memberi poin. Seandainya peserta didik diberi penguatan terhadap penguatan maka itu akan menjadi pengalaman peserta didik.

Kenyataannya, bahwa peserta didik SD Negeri 16 kecamatan Sungayang berada pada periode berpikir konkrit, kesulitan dalam mengerjakan tugas pada mata pelajaran matematika dan ia memerlukan penguatan. Diasumsikan sistem token economy efektif bagi mereka. Sebagaimana yang dikemukakan oleh Thornburg (1984: 440) bahwa "another type of reinforcing procedure especially effective for students who are unresponsive to 'regular' school reinforcers is the token economy system". Maksudnya bahwa jenis lain untuk memperkuat perilaku yang sangat efektif bagi peserta didik yang tidak berlaku lagi bagi mereka penguatan yang 'biasa' adalah sistem token economy. Pada dasarnya, sistem ini berkaitan dengan penggunaan penguatan yang netral, tetapi hal itu memperoleh penguatan ketika penguatan itu dibina menjadi rangsangan yang mengarah kepada penyokongan penguatan (tadinya netral, tapi bisa dibina menjadi penguatan yang menyokong). Penguatan ini bisa diraba dan tidak bisa diraba, seperti hadiah istimewa atau suatu penguatan "nyata": contohnya uang, makanan, mainan dan sebagainya.

Anak yang mengerjakan tugas, ia distimulus dengan token, reaksinya ia akan sering mengerjakan tugas. Setiap ia melakukan tingkahlaku baik diberi respon, lama-lama ia akan menjadi miliknya tanpa dihubungkan dengan stimulus asli (token). Ada pun bentuk token tersebut adalah pertukaran antara bintang, potongan kertas teka-teki, permen atau permen karet dan sebagainya dengan berbagai bentuk tingkahlaku yang diharapkan perubahannya.

McLeod (2008) mengemukakan bahwa token economy dapat menjadikan perilaku peserta didik dikuatkan secara konsisten kearah yang diinginkan. Kenyataan yang terjadi di SD Negeri 16 Kecamatan Sungayang, guru belum pernah menerapkan sistem token economy dalam proses pembelajaran, termasuk untuk mendorong peserta didiknya senang menyelesaikan tugas matematika yang dianggap bermasalah.

Berdasarkan uraian di atas, dapat dipahami bahwa guru SD sangat menentukan pengalaman peserta didik terhadap masa depannya. Maka mengapa guru SD harus menyerah dan merasa kawalahan menghadapi tingkahlaku peserta didik yang bermasalah dalam penyelesaian tugas pada mata pelajaran matematika, jika token economy belum dicobakan? Diharapkan, peserta didik SD yang memperoleh token economy tidak akan kehilangan motivasi belajar pada tingkat pendidikan yang lebih tinggi. Apalagi peserta didik SD berada pada 
periode industri, penerapan token economy yang bervariasi dan menarik semoga dapat merangsang tumbuh dan kembangnya ide kreatifitas peserta didik tersebut.

Oleh karena itu, perlu dipelajari lebih lanjut tentang token economy dalam menyelesaikan tugas matematika peserta didik kelas V SD Negeri 16 kecamatan Sungayang. Tujuan penelitian ini adalah untuk mendeskripsikan penerapan token economy dalam membantu pemecahan masalah penyelesaian tugas mata pelajaran matematika di kelas V SD Negeri 16 Kecamatan Sungayang.

\section{METODOLOGI}

Penelitian ini menggunakan metode kualitatif dengan jenis studi kasus. Subjek penelitian adalah 3 orang kasus yang paling bermasalah dalam penyelesaian tugas pada mata pelajaran matematika di kelas.

Instrumen dalam penelitian ini adalah menggunakan teknik pengamatan/observasi. Alat yang digunakan untuk mengumpulkan data adalah format observasi. Data dikumpulkan dan disusun dalam bentuk tabel serta melampirkan semua dokumen yang diperoleh dan dikaji dengan cara saling menghubungkan kaitan-kaitannya yang serba beraneka ragam. Untuk pemeriksaan keabsahan data yang diperoleh, maka dilakukan observasi berulang kali dan wawancara dengan guru kelas.

\section{HASIL}

Temuan penelitian mengungkapkan penerapan token economy dimodifikasi dengan pemberian kepingan puzzle untuk merespon kecenderungan yang terjadi dalam pengubahan tingkahlaku selama menyelesaikan tugas pada mata pelajaran matematika di kelas. Token dapat menjadi salah satu alasan peserta didik mengerjakan tugas. Token yang mereka kumpulkan seiring dengan dipenuhinya apa yang diharapkan dalam mengerjakan tugas pada mata pelajaran matematika di kelas. Kasus yang memunculkan sejumlah tingkahlaku yang diharapakan selama penyelesaian tugas mereka akan menerima sejumlah token.

Penerapan token economy diawali dengan penjelasan secara klasikal dan secara detail difokuskan kepada peserta didik yang menjadi objek penelitian. Kepada mereka diberikan masing-masing selembar kertas perjanjian: penyelesaian tugas atau latihan yang berisikan aspek yang diobservasi, selanjutnya mereka tandatangani.

1. Kehadiran Ketika Penugasan

Dari temuan penelitian, diketahui ada kasus yang bermasalah dengan kehadiran selama penyelesaian tugas, ada yang hadir tapi tidak mengerjakan tugas dan ada yang sering tidak hadir baik ketika ada pelajaran matematika maupun pada hari-hari lain.

2. Membaca/mendengarkan Soal Tugas dengan Baik

Dari temuan penelitian, diketahui membaca/mendengarkan soal tugas dengan baik sering tidak dilakukan oleh kasus.

3. Kelengkapan dan Pemanfaatan Bahan Tugas

Dari temuan penelitian diketahui ketidak tersediaan atau tidak lengkap bahan tugas dapat mengganggu penyelesaian tugas. Ada kasus yang sering tidak lengkap bahan tugas, akibatnya ia harus menunggu pinjaman dari teman, menggangu teman, tidak konsentrasi, tugas menjadi tidak rapi, tidak bersih dan lain sebagainya.

4. Kejelasan, Kerapian dan Kebersihan Jawaban Tugas

Dari temuan penelitian diketahui ada kasus yang menyelesaikan tugas menjadikan guru bingung memeriksanya. karena tidak jelas. Tugas menjadi tidak menarik untuk dibaca karena tidak bersih dan tidak rapi. Ada kasus yang mengotori tugasnya dengan mencoret kesalahan sampai hitam dan tidak dapat dibaca. Kalau tugas sudah banyak coretan hitam, tentu saja tugas menjadi tidak rapi.

5. Kesungguhan, Tidak Mengganggu Teman dan Konsentrasi dalam Penyelesaian Tugas Dari temuan penelitian diketahui ada kasus yang suka mengganggu temannya. Kasus baru mulai menerima token terkait item ini ketika ia sakit. Kasus hanya duduk di mejanya memperhatikan kelasnya tanpa melakukan apapun, termasuk mengganggu temannya.

6. Ketepatan Jawaban Tugas, Kecepatan Menyelesaikan Tugas dan Menyerahkan Tugas Tepat Waktu Ada kasus yang menyelesaikan tugas asal cepat mengumpulkannya tanpa memperhatikan ketepan jawaban tugas. Ada juga kasus yang menyerahkan tugas tepat namun lalai dan menyerahkan lewat batas waktu yang telah ditentukan. 


\section{PEMBAHASAN}

Penerapan token economy diawali dengan penjelasan secara klasikal dan secara detail difokuskan kepada peserta didik yang menjadi objek penelitian. Kepada mereka diberikan masing-masing selembar kertas perjanjian: penyelesaian tugas atau latihan yang berisikan aspek yang diobservasi, selanjutnya mereka tandatangani. Hal tersebut mencoba menerapkan apa yang diilustrasikan Thornburg (1984) tentang bagaimana sebuah strategi praktis untuk pengendalian diri, yaitu kontrak perilaku antara peserta didik dengan guru, di dalamnya peserta didik menerima persetujuan untuk mencapai tugas-tugas tertentu. Kontrak harus fokus secara khusus pada daerah perubahan perilaku yang diinginkan berubah.

Pernyataan Thornburg di atas, bermula dari apa yang dikemukakan oleh para teori respon bersyarat, tingkahlaku yang terbentuk harus dapat diamati (Thornburg: 1984, Santrock \& Yussen: 1997, McLeod: 2008, Hackenberg: 2009). Dalam penelitian ini tingkahlaku yang diamati selama penyelesaian tugas matematika di kelas.

1. Kehadiran Ketika Penugasan

Kehadiran perlu diperbaiki. Pemberian token dapat memperbaiki hal tersebut. Slameto (2013) mengemukakan mengenai petunjuk pelaksanaan tugas diantaranya adalah tentang kehadiran lebih awal dari waktu yang sudah ditentukan. Hal tersebut jelas memperkuat alasan tentang pentingnya kehadiran termasuk dalam penyelesaian tugas.

2. Membaca/mendengarkan Soal Tugas dengan Baik

Membaca/mendengarkan soal tugas dengan baik perlu dilakukan, untuk itu penerapan token economy mencoba untuk mempengaruhinya. Prayitno, Alizamar, Taufik, Syahril, \& Prayitno (2002) mengemukakan terkait mutu tugas diantaranya adalah penyelesaian tugas harus sesuai dengan soal. Hal tersebut juga didukung oleh pendapat Slameto (2013) bahwa agar berhasil dalam menyelesaikan tugas hendaknya duduk dengan tenang sambil menunggu soal dibagikan, mulai membaca (jika soal tertulis) atau dengarkanlah (jika tugas diberikan dalam bentuk lisan), pahami dengan baik untuk memperoleh gambaran menyeluruh pertanyaan guru dengan baik, teliti dan penuh perhatian. Oleh karena itu, membaca/mendengarkan soal tugas dengan baik perlu menjadi perhatian guru. Penerapan token economy dapat membantu garu memperbaiki hal tersebut.

3. Kelengkapan dan Pemanfaatan Bahan Tugas

Bahan tugas dapat menjadi salah satu hal dan kondisi yang mempengaruhi penyelesaian tugas. Hal tersebut sesuai dengan apa yang dikemukakan Prayitno, Alizamar, Taufik, Syahril, \& Prayitno (2002). Selanjutnya didukung oleh Slameto (2013) bahwa agar peserta didik mengerjakan tugas dengan sebaik-baiknya perlu dilaksanakan persiapan segala alat/perlengkapan-perlengkapan yang diperlukan seawal mungkin. Oleh karena itu, ketersediaan dan pemanfaatan bahan tugas memang perlu menjadi perhatian.

4. Kejelasan, Kerapian dan Kebersihan Jawaban Tugas

Jawaban tugas hendaklah jelas, rapi dan bersih. McLaughlin \& Malabi (1972) Memberikan token kepada subjek yang mengerjakan tugas dengan rapi. Selanjutnya Prayitno, Alizamar, Taufik, Syahril, \& Prayitno (2002) mengemukakan salah satu hal dan kondisi yang mempengaruhi penyelesaian tugas adalah kejelasan tugas dan hal penting yang perlu diperhatikan dalam penyelesaian tugas adalah mutu tugas, misalnya kebersihan dan kerapian tugas. Berikut Slameto (2013) mengemukakan salah satu petunjuk agar dapat berhasil dalam menyelesaikan tugas adalah tugas harus jelas, baik dan rapi. Namun yang terjadi, dari temuan penelitian diketahui ada kasus yang menyelesaikan tugas menjadikan guru bingung memeriksanya karena tidak jelas. Tugas menjadi tidak menarik untuk dibaca karena tidak bersih dan tidak rapi.

5. Kesungguhan, Tidak Mengganggu Teman dan Konsentrasi dalam Penyelesaian Tugas Slameto mengemukakan salah satu langkah persiapan dalam menghadapi tugas adalah konsentrasikan seluruh perhatian terhadap tugas yang dihadapi. Selanjutnya, agar berhasil jangan terpengaruh oleh teman lain. Ini menggambarkan bahwa dalam penyelesaian tugas dibutuhkan kesungguhan.

6. Ketepatan Jawaban Tugas, Kecepatan Menyelesaikan Tugas dan Menyerahkan Tugas Tepat Waktu McLaughlin \& Malabi (1972) memberikan token untuk semua jumlah item yang dijawab dengan benar. Selanjutnya Prayitno, Alizamar, Taufik, Syahril, \& Prayitno (2002) mengemukakan hal penting yang perlu diperhatikan dalam penyelesaian tugas adalah tugas perlu dikerjakan dalam waktu yang cukup dan sesuai dengan batas masa berakhirnya penugasan tersebut. Pendapat tersebut juga didukung oleh apa yang dikemukakan Slameto (2013) bahwa, agar dapat berhasil dalam penyelesaian tugas perhitungkan waktu yang disediakan untuk mengerjakan tugas. Sebaiknya dikerjakan soal yang mudah dulu dan jawablah dengan tepat, 
padat dan jelas. Akhirilah tepat pada waktunya tugas itu dan serahkan. Oleh karena itu, perlu sekiranya agar peserta didik memperhatikan ketepatan jawaban tugas dan perhitungan waktu untuk menghasilkan tugas yang baik.

Dari temuan penelitian dapat dipahami bahwa banyak persoalan tingkahlaku kasus yang perlu diperbaiki agar berhasil dalam menyelesaikan tugas. Penerapan token economy dapat memperbaiki hal tersebut. Termasuk memperbaiki ada kasus yang sering mendapat perhatian guru, namun ia tetap dengan tingkahlaku buruknya, hal tersebut dapat dikatakan bahwa perhatian guru itu sudah menjadi biasa bagi kasus tersebut, sehingga itu sudah tidak berpengaruh lagi bagi dia dalam memperbaiki tingkahlakunya. Melalui pnenerapan token economy ini, tingkahlaku kasus dapat dipengaruhi. Hal tersebut sama dengan apa yang dikemukakan Thornburg (1984: 440) bahwa "another type of reinforcing procedure especially effective for students who are unresponsive to 'regular' school reinforcers is the token economy system". Maksudnya adalah jenis lain untuk memperkuat perilaku yang sangat efektif bagi peserta didik yang tidak berlaku lagi bagi mereka penguatan yang 'biasa' adalah sistem token economy.

Berdasarkan deskripsi temuan penelitian, pada tiga minggu pertama token diberikan langsung oleh guru kelas untuk merespon tingkahlaku yang diharapkan. Namun guru memberikan dengan menghitung berapa jumlah token yang didapat oleh peserta didik, atau bukan mengatakan ia memperoleh token untuk apa. Sehingga yang terjadi pemberian token tidak jelas oleh peserta didik akibatnya tingkahlaku yang diharapkan berubah atau diharapkan bertahan tidak terjadi.

Pada awal minggu keempat, pemberian token langsung peneliti yang memberikan untuk merespon tingkahlaku yang diinginkan, karena pada minggu ini peneliti merasa sudah akrab dengan peserta didik yang ditandai dengan senangnya mereka meminta penjelasan lebih lanjut tentang tugas yang harus mereka kerjakan. Awalnya mereka hanya mengumpulkan beberapa saja, namun akhirnya mereka berusaha untuk memperoleh token lebih banyak untuk tugas berikut.

Terkait tingkahlaku peserta didik dalam menyelesaikan tugas dari temuan penelitian yang telah dijelaskan, dapat dipahami bahwa penerapan token economy dapat mendorong peserta didik untuk memperbaiki tingkahlakunya. Hasil tugas dapat meningkat dan dapat dipertahankan jika alasan perolehan token jelas oleh mereka. Selanjutnya yang memberi token pun harus benar-banar sudah akrab atau dekat dengan penerima token. Ini membuktikan apa yang dikemukakan oleh Piaget (dalam Mayer: 1987) bahwa kemampuan berpikir peserta didik usia SD berada pada periode berpikir konkrit, proses pembelajaran beranjak dari hal yang nyata. Hal tersebut sejalan dengan apa yang dikemukakan oleh Jamaris (2014) bahwa dalam usaha menanggulangi kesulitan belajar matematika yang dialami peserta didik di SD, maka hal yang penting adalah memberikan pengalaman belajar secara konkrit. Penerimaan token adalah nyata, nampak dan dapat dirasakan langsung oleh kasus, ia juga mengerti mengapa ia memperoleh token.

Oleh karena itu, dapat dirasakan manfaat token economy bagi kasus dalam penyelesaian tugas matematika. Hal tersebut sama dengan apa yang dikemukakan oleh Hackenberg (2009) tentang manfaat token economy sebagai manajemen tingkahlaku dan alat motivasi dalam bidang pendidikan. Sejalan dengan data yang dipaparkan Birnbrauer, Wolf, Kidder, \& Tague; McKensie, Clark, Wolf, Kothera, \& Benson; O'Leary, Becker, Evans, \& Saudargas (dalam McLaughlin \& Malabi: 1972) tentang efektivitas token economy untuk pengubahan berbagai perilaku pendidikan dalam kelas. Penelitian McLaughlin \& Malabi tentang efek token economy pada penyelesaian tugas untuk seluruh kelas, menghasilkan bahwa token economy secara signifikan dapat membantu penyelesaian tugas.

Dari hasil temuan penelitian ditemukan ada kasus yang suka mengganggu atau mengusili temannya, ia mudah terpengaruh oleh keadaan disekitar, melalui penerapan token economy hal tersebut dapat diatasi. Temuan penelitian ini sama dengan hasil penelitian oleh Zlomke \& Zlomke (2003) tentang efektivitas token economy untuk mengurangi perilaku agresif yang sangat mengganggu di dalam kelas, menunjukkan bahwa penurunan jumlah perilaku yang ditargetkan melampaui pengurangan penggunaan token economy.

Peningkatan jumlah pengumpulan token seiiring dengan meningkatnya kualitas tugas karena kejelasan pemberian token. Hal tersebut membuktikan apa yang dikemukakan Prayitno (2009) bahwa tingkahlaku peserta didik yang hendak diperkuat (dalam hal ini, yang diberi token) hendaklah jelas; bentuk tingkahlaku yang baik itu, jelas pula apanya yang baik. Hal ini senada dengan yang dikemukakan Johnson (2005) bahwa guru harus fokus menghargai perilaku baik dalam bentuk memberikan hadiah. Oleh karena itu, dengan kejelasan tingkahlaku yang 
direspon dengan token dan alasan mengapa peserta didik menerima token akan terasa betapa manfaatnya token mempengaruhi tingkahlaku peserta didik.

Dari uraian temuan penelitain terkait waktu pengerjaan dan penyelesaian tugas, bahwa penerapan token economy dapat mempengaruhi peserta didik dalam mengatur waktu pengerjaan dan penyelesaian tugas. Penerimaan token oleh peserta didik dapat merubah kebiasaannya. Hal tersebut sama dengan temuan penelitian Hackenberg (2009) mengemukakan bahwa banyak penelitian tentang pemanfaatan token economy diantaranya sebagai koordinasi terhadap tingkahlaku ketepatan waktu. Terpenuhinya petunjuk agar berhasil menyelesaikan tugas yang dikemukakan oleh Slameto (2013) perhitungkan waktu yang disediakan untuk mengerjakan, akhirilah tepat pada waktunya tugas itu dan serahkan.

Berdasarkan deskripsi temuan penelitian dan pembahasan dengan hasil penelitian terdahulu dan pendapat ahli lainya, dapat dipahami bahwa token economy dapat memberikan manfaat dalam penyelesaian tugas matematika di kelas. Penerapan token economy sangat disenangi oleh kasus dan peserta didik yang tidak menjadi objek penelitian pun menyukai hal tersebut.

\section{KESIMPULAN}

Berdasarkan hasil penelitian, dapat dikemukakan beberapa kesimpulan, yaitu:

1. Penerapan token economy dimodifikasi dengan pemberian kepingan puzzle untuk merespon kecenderungan yang terjadi dalam pengubahan tingkahlaku selama penyelesaikan tugas pada mata pelajaran matematika di kelas. Token dapat menjadi salah satu alasan peserta didik mengerjakan tugas.

2. Penerapan token economy dapat membantu pemecahan masalah tingkahlaku peserta didik dalam penyelesaian tugas.

3. Penerapan token economy dapat mendorong peserta didik untuk memperbaiki kualitas tugasnya.

4. Penerapan token economy dapat merubah kebiasaan peserta didik dalam mengatur waktu pengerjaan dan penyelesaian tugas.

\section{IMPLIKASI}

Penerapan token economy dapat membantu pemecahan masalah tingkahlaku peserta didik dalam penyelesaian tugas. Prosedur ini sangat disenangi oleh para peserta didik. Token dapat dimodifikasi dengan berbagai bentuk permainan yang menarik peserta didik, mudah digunakan dan dapat diterapkan dalam berbagai bentuk kegiatan. Begitu juga dalam kegiatan bimbingan konseling, konselor dapat menjadikan penerapan token economy dalam pemberian layanan bimbingan dan konseling, tidak hanya pada layanan penguasaan konten tentang konten dalam menyelesaikan tugas-tugas belajar saja, tapi juga pada praktik kegiatan layanan lainnya. Selanjutnya konselor dapat berkolaborasi dengan guru matapelajaran untuk memperbaiki tingkahlaku atau dalam rangka meningkatkan mutu belajar peserta didik dengan menerapkan token economy.

\section{SARAN}

Setelah memperhatikan hasil penelitian dan kesimpulan di atas, maka selanjutnya dikemukakan saran sebagai berikut.

1. Bagi para peserta didik yang menjadi fokus penelitian ini diharapkan mempertahankan tingkahlaku yang sudah diperbaiki melalui penerapan token economy.

2. Bagi guru-guru kelas agar dapat menerapkan token economy, yang dimodifikasi dengan bentuk token lain dan tingkahlaku lain yang diharapkan perubahannya dalam proses pembelajaran.

3. Bagi konselor sekolah agar dapat menerapkan token economy untuk mendukung pelaksanaan pemberian layanan bimbingan dan konseling, tidak hanya pada layanan penguasaan konten tentang konten dalam menyelesaikan tugas-tugas belajar saja, tapi juga pada praktik kegiatan layanan lainnya. Konselor hendaknya berkolaborasi dengan guru matapelajaran untuk memperbaiki tingkahlaku atau dalam rangka meningkatkan mutu belajar peserta didik dengan menerapkan token economy.

4. Bagi pimpinan Program Studi S2 Bimbingan Konseling Fakultas Ilmu Pendidikan Universitas Negeri Padang, agar dapat memberikan khasanah terhadap hasil penelitian ini untuk praktik kegiatan bimbingan dan konseling dan pedoman atau dasar penelitian berikutnya.

5. Kepada peneliti selanjutnya, dapat menerapkan token economy dalam konteks yang berbeda untuk memperoleh gambaran lebih luas tentang token economy. 


\section{DAFTAR RUJUKAN}

Hackenberg, T. D. 2009. "Token Reinforcement: a Review and Analysis". Journal of The Experimental Analysis of Behavior, 91 (2): 257-286.

Hergenhahn, B. R., \& Olson, M. H. 2008. Theories Of Learning (Teori Belajar) (Edisi Ketujuh). Terjemahan oleh Tri Wibowo B.S. 2008. Jakarta: Kencana Prenada Media Group.

Jamaris, M. 2014. Kesulitan Belajar: Prespektif Asesmen, dan Penanggulangannya Bagi Anak Usia Dini dan Usia Sekolah. Jakarta. Ghalia Indonesia.

Johnson, L. 2005. Pengajaran yang Kreatif dan Menarik: Cara Membangkitkan Minat Siswa Melalui Pemikiran. Terjemahan oleh Dani Dharyani. 2009. Jakarta: PT Indeks.

Mayer, R. E. 1987. Educational Psychology: a Cognitive Approach. Boston: Little, Brown and Company.

McLaughlin, T. F., \& Malaby, J. 1972. "Intrinsic Reinforcers In a Classroom Token Economy: Sponkane School District 81 and Eastern Washington State College". Jurnal of Applied Behavior Analisis, 5 (3): 263-269.

McLeod, J. 2003. An Introduction to Counseling (Pengantar Konseling: Teori dan Studi Kasus). Terjemahan oleh A. K. Anwar. 2008. Jakarta: Kencana Prenada Media Group.

Prayitno. 2009. Dasar Teori dan Praksis Pendidikan. Jakarta. Grasindo

Prayitno, Alizamar, Taufik, Syahril, \& Prayitno, E. 2002. Seri Latihan Keterampilan Belajar (Program Semi Que IV). Padang: BK FIP UNP.

Santrock, J. W., \& Yussen, S. R. 1987. Child Development: An Introduction. Amerika: WM. C. Brown Publishers.

Slameto. 2013. Belajar dan Faktor-faktor yang Mempengaruhinya. Jakarta: Rineka Cipta.

Thornburg, H. D. 1984. Introduction To Education Psychology. New York: West Publishing Company.

Zlomke, K., \& Zlomke, L. 2003. "Token Economy Plus Self-Monitoring to Reduce Disruptive Classroom Behaviors". Jurnal The Behavior Analyst Today, 4 (2): 177-181. 